\title{
Using Mobile-Assisted Language Learning (MALL) to Teach English in Indonesian Context: Opportunities and Challenges
}

\section{${ }^{*}$ Solihin}

STKIP Paracendekia NW Sumbawa, Indonesia

\section{Correspondence*}

solihin.mohe@gmail.com

Submission History:

Submitted: February 02, 2021

Revised: August 02, 2021

Accepted: September 09, 2021

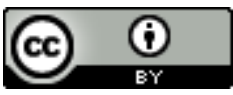

This article is licensed under a Creative Commons Attribution 4.0 International License.

\begin{abstract}
In the realm of education, information technology (IT), particularly mobile devices and applications, is becoming increasingly popular. Language learning has become one of the areas of education where mobile technology is being used. In Indonesia, Mobile-Assisted Language Learning has been implemented some areas, while it is acknowledged that some areas have not benefited as much as others. Some have questioned whether MALL might be used in their areas, while others have stated that it is unavoidable. The following are the research questions: 1) what are the advantages and disadvantages of using MALL? 2) How feasible is it to utilize MALL in an Indonesian context? The nature of this study is descriptive qualitative. The data collection methods used was library research. Data reduction, data display, and conclusion drawing were the approaches used to analyze the data. This research examines a variety of literature (including peer-reviewed studies) on the benefits and drawbacks of adding MALL into the framework of English as a Foreign Language (EFL) education. The application of these concepts in an Indonesian setting is then examined. Finally, to stay up with global digital learning, this article advocates that MALL be used for EFL teaching in Indonesia. It also suggests that more research be done for each mobile device and app in various parts of Indonesia, particularly in rural and remote places.
\end{abstract}

Keywords: MALL, Indonesia, Opportunities, Challenges

\section{INTRODUCTION}

Because of technological advancements, the world of education has altered drastically. As a result, teachers must be able to keep an eye on current technology use and development, including Mobile-Assisted Language Learning, and then use it to assist them in teaching. Because today's age enjoys performing a variety of things with their mobile 
devices such as iPhones, iPads, and Tablets, MALL is becoming more vital for Indonesian teachers to consider for its use (Espinosa, 2015; Godwin-Jones, 2011). Language has even been built into some mobile devices to make it easier for users to learn and understand. As a result, a better understanding of their utility in foreign language instruction is required.

Several experts have argued that, unlike computer-assisted language learning (CALL), which relies on a computer or laptop, MALL makes use of mobile technologies such as smartphones and tablets to enable and support language learning during the day (Chuang, 2009; Ozdogan, Basoglu, \& Ercetin., 2012). Others agree with this trend, claiming that MALL can help students learn languages more effectively (Ahmad, Armarego, \& Sudweeks, 2013). Furthermore, MALL devices are beneficial in the learning of languages. This is due to its widespread availability, convenience, portability, and accessibility in a variety of countries, including Indonesia.

As mobile technology has grown in popularity, advanced applications for language learning have emerged. According to the results of a Pew Research Center Project for Excellence in Journalism poll conducted in 2012, half of all American adults own a smartphone or tablet (Fox and Duggan, 2012 cited in Ahmad et al., 2013). This demonstrates that in the recent decade, the use of these two mobile devices has skyrocketed. Furthermore, the rising use of mobile device technology has been significantly improved and integrated. Apart from traditional phone use (oral communications and text messaging), modern mobile technology has been built to let consumers access the internet from a variety of locations. Users can use it to find addresses, search for information, send emails, read e-books, and even shop. In the case of language study, the devices' mobility has facilitated autonomous learning from anywhere and at any time, even outside of the classroom.

However, some English teachers have stated that using MALL in language learning is still difficult for them. This is especially true in undeveloped and emerging countries like Indonesia, which is made up of several islands. Some Indonesian regions have progressed to the point where their educational institutions may employ MALL. Other regions, on the other hand, find it difficult, if not impossible, to implement MALL in their educational institutions. The most recent news mentioned by Lombok Post (2020), 3.000 villages in Indonesia are still without electricity, and 11.000 have no access to the internet. For example, it is estimated that 44 sub-villages in Sumbawa regency, West Nusa Tenggara Province, do not have access to power. As a result of this occurrence, 5.000 families are unable to utilize any electrical gadgets or services. Moreover, out of 24 sub-districts in the Sumbawa, only 2 have the access to electricity 24 hours (Merdeka.com, 2020). These situations certainly make it difficult to implement MALL in these regions in educational institutions.

As a result, to assess the feasibility of MALL in the Indonesian setting, particularly in rural areas, resources relevant to the potential and constraints of MALL must be analyzed and documented. 


\section{METHOD}

The goal of this research was to look at the benefits and drawbacks of using MALL in Indonesia, particularly in rural areas. This study has reviewed 30 articles to meet this need. They were chosen based on the types of mobile devices they mentioned as well as their assessment of the obstacles and opportunities of implementing MALL in other countries, including Indonesia. This study used a descriptive qualitative method. This indicates that the study gives descriptive data on the issues investigated (Sugiyono, 2010). It looked at articles authored by a variety of researchers, including peer-reviewed articles. The method of data collection used in this study was library research. Library research, according to Princeton University (2021), entails some processes, including keyword searches, subject searches, and citation searches. The steps used in this study were to first identify and then search for key terms connected to this research. The researcher first gathered related and current studies as part of the data collection process. The data was then evaluated by the researcher. The next stage was to portray the material as a whole. Finally, a decision was made.

\section{RESULTS AND DISCUSSION}

\section{Opportunities of Using MALL in General}

Some mobile devices and applications in foreign language instruction have been studied by several academics. Chinnery (2006) examined an empirical study that utilised mobile technology for language acquisition, such as cell phones, iPods, and PDAs. In a similar spirit, Yang (2013) has described a number of new mobile technology uses, including short message services (SMS), microblogging, and GPS. Additionally, Bensalem (2018) has conducted research on the impact of Whatsapp use on EFL students' vocabulary learning. They all concluded that those mobile devices and applications should be actively examined for keeping up with modern technology for language learning because they offer a variety of benefits.

In general, MALL has a variety of advantages for foreign language. For starters, it makes language learning easier for both teachers and students. Teachers can assign a variety of tasks utilizing particular mobile devices and applications, with no time or location constraints. Second, both teachers and students can benefit from global connectivity and education. In other words, they have more opportunities to study languages and receive education from people from different areas or countries (Wishart, 2008). Immediacy, portability, individualism, connectivity, and context-sensitivity are all features it offers (Lan, Sung, and Chang, 2007).

\section{Specific Opportunities}


The following explanations are about the prospects for foreign language learning that can be achieved through a variety of mobile devices and applications.

\section{Mobile Devices}

\section{Personal Digital Assistants (PDAs)}

PDAs are mobile gadgets similar to cell phones, iPods, and tablet computers. Rather of being called mobile phones, they are referred to as m-learning devices (Chinnery, 2006; Yang, 2013). Many educational institutions, including high schools, medical schools, and higher education institutions, have used them (Carlon, 2002 as cited in Chinnery, 2006; Jang \& Song, 2007). In foreign language teaching, their primary role is that of a translator. As a result, they've been dubbed "talking phrasebooks" (Chinnery, 2006). Other features of PDAs include internet and wireless access. As a result, transferring files between teachers and students, as well as students and students, is easier.

PDAs for foreign language teaching and learning have been found to be successful and beneficial to students' academic achievement in their studies. Myers (2000 used managed translators to observe and evaluate the successes of Chinese English language learners. The students were found to be able to swiftly improve their spelling. Students' cognitive interest in utilizing PDAs is particularly substantial, according to Park, Kim, Lee, Son, and Lee (2005). More foreign language learning programs are being produced in PDAs these days. In a Spanish business course evaluated by Gabere (2002), it was reported that the students were highly motivated and impressed by the use of video and multimedia features of the PDAs (as cited in Chinnery, 2006).

Tablet computing, for example, has been shown in some studies to help teachers and students teach and learn a foreign language more effectively (Yang, 2013). Lan, Sung, and Chang (2007) conducted a comparison study to examine the advantages of using Tablet Computing in an EFL setting. The goal of this study was to see if using Tablet PCs in a reading class may improve collaborative learning compared to a typical classroom setting. The findings revealed that using Tablet PCs to facilitate collaborative learning between students overcame the disadvantages of traditional classroom settings.

Savas (2014) looked into how successful Tablet PCs are as teaching and learning instruments in EFL classes from the perspective of 40 pre-service English teachers. This research was conducted in a Turkish governmental university. Two questionnaires were utilized in the data collection process. The majority of pre-service EFL teachers evaluated Tablet PCs as effective instructional tools in teaching most of the subcomponents of English, according to the results of quantitative data analysis.

\section{Mobile Applications \\ WhatsApp}

WhatsApp is a free program that allows users to send and receive text messages and make phone calls. It also has content sharing options including photographs, video, audio, location, and emojis. It is compatible with Android, Blackberry, and Apple devices. It is 
believed to be the most commonly used instant messaging service in the world today, with over 1.2 billion monthly active users (The Statistical Portal, 2018). Because of its popularity, many educators are interested in exploring its possibilities for teaching and learning a second language (Bensalem, 2018). Some research focusing on using this program in foreign language instruction demonstrates that it is a useful technical tool for learning various aspects of the language, such as vocabulary, collocations, and punctuation (Awada, 2016; Bensalem, 2018; Hamad, 2017).

The more particular chances for foreign language education that can be employed with this application are found in its features. Emojis can be used to teach writing, speaking, and other skills, for example. For example, assigning students to find their partners to form a WhatsApp group can be used to teach writing. They are then prompted to send each other emojis. They are then given the task of describing the emojis delivered by their partners (Oxford University Press ELT, 2016). They can then be invited to correct one other's descriptive statements as a follow-up task. Although the teacher must be the final corrector and feedback giver on all students' work, this method supports collaborative learning because students are allowed to work together and debate their outcomes (Mwakapina, Mhandeni, \& Nyinondi, 2016 2016).

\section{Facebook}

Facebook's popularity has exploded in the recent decade. It is a social networking site or online communication tool that can be used to collaborate and engage with a virtual community (Boyd \& Ellison, 2007). It can be viewed via the internet or an app installed on iPhones, iPads, and Tablets. Not only is it widely utilized by the general public, but it has also become popular among students and professors, who use it to communicate with one another (Noordin \& Ting, 2017). Some teachers and students have even tried to utilize Facebook to study English as a foreign language, according to the authors' experiences.

Many academics have looked into its potential as a foreign language learning tool because it has a wide range of technological features. Noordin and Ting (2017) investigated how 150 high school students in an EFL context used Facebook to enhance their language acquisition. According to the findings, the majority of pupils accessed Facebook at least once a day. To put it another way, Facebook has become a daily tool for students to engage with one another. They utilized it for a variety of purposes, including changing their status, talking, texting pals, and leaving comments on other people's posts.

Espinosa (2015) investigated whether it was possible to combine online social networking, such as Facebook, with traditional foreign language training in order to inspire students and improve their English language learning. It was discovered that Facebook might be used in conjunction with traditional or conventional instruction. Facebook might also be used to inspire kids to study English and enhance their motivation, according to reports. 


\section{Microblogging (mobile blogging)}

Microblogging is a mobile phone blogging device that symbolizes Mobile 2.0 technology (Ebner, Lienhardt, Rohs, \& Meyer, 2010; Yang, 2013). It is a hybrid of blogging and messaging that allows users to post short messages, typically between 140 and 280 characters (Nations, 2018 \& Meyer, 2010; Yang, 2013). Mobile blogging has taken several forms, including Twitter, Instagram, and Tumbler (Borau, Ullrich, Feng, and Shen as cited in Yang, 2013). Yang (2013) studied a microblogging tool in his research (i.e. Twitter). It was discovered to be an effective instrument for foreign language instruction.

Menkhoff, Chay, Bengtsson, Woodard, and Gan (2015) looked into how pedagogical tweeting may be utilized to solve the problem of students who don't want to participate in class. Twitter has been regarded as an excellent technique for getting students involved in the class. This was due to the fact that students could access it via a website and an app on iPhones, Android phones, and computers. It was done by, for example, discussing in-class and out-of-class questions or providing advise and feedback on tasks (by the teacher). The students might then tailor the conversation outcomes and collaborative knowledge generation to their particular situations (Menkhoff et al., 2015).

\section{Challenges of Applying MALL in the Teaching of English in Indonesia}

Teachers, students, mobile devices, and applications all play a role in the problems of using MALL in English instruction in Indonesia. There are further problems related to cultural or ethical issues, as well as the conditions in Indonesian regions.

\section{Challenges for teachers}

Many teachers who have been teaching using traditional methods of education may find it challenging to transition to MALL-based modern foreign language instruction. Teachers who are unfamiliar with mobile devices or programs, such as Facebook, may be unable to effectively use them in foreign language instruction. Furthermore, nearly limitless access to material based on their educational environment may result in information overload, particularly if teachers are not adept at finding relevant information (Salehi \& Salehi, 2012). Older teachers may lack the necessary abilities to incorporate mobile devices and applications into their classrooms. In other words, they lack technological pedagogical content knowledge (TPACK) (Hsu, 2016). To put it another way, they lack TPACK (technological pedagogical content knowledge) (Hsu, 2016). Some older teachers are believed to have technophobia and refuse to use any electronic devices in their classrooms (Oxford University Press ELT, 2016).

Teachers may not be aware of how to connect mobile devices and applications to the teaching of English as a topic. Teachers may not understand what emotions emojis represent in Whatsapp, or how to use the video call tool for English discourse, for example. Teachers may not yet grasp how to form a tight group for learning activities while utilizing Facebook for educational purposes. Similarly, they may need to set aside additional time to learn about tablet computing's features. All of these things appear to be difficult for them. 


\section{Challenges for students}

Students may confront a variety of problems when utilizing MALL. For starters, students may lack the knowledge of how to use and connect learning activities to those apps and devices. Furthermore, unrestricted access to information via mobile devices and applications may divert students' attention away from their studies. Mobile device use and presence in class are on the rise, which can lead to interruptions and diversions (Campbell, 2005; 0z, 2015). This shows that students may be unable to resist their impulses to do things with their devices that are not necessary, such as opening game advertising that appearson Facebook. Furthermore, they may develop an addiction to such products. Second, they may waste time conversing, updating their status, and commenting on other people's postings, which may or may not be related to or important for their language study. For example, they may post things in their first language that are solely about their thoughts about their female friends (Ali, 2018).

\section{Cultural and ethical challenges}

When using old techniques of teaching English, some teachers are confident, but when adopting current (alternative) approaches, they are fearful and insecure (Wishart, 2008). This is a habit that MALL has as well. Some people are even hesitant to use technological equipment because they lack the necessary skills or knowledge. As a result, individuals tend to shy away from modern devices. In a few Indonesian English classes, this phenomenon has established a "culture." Culturally, some parents and even schools prohibit pupils from bringing cell phones to school due to the potential for disruption. These issues may constraint the use of MALL in English classes.

Ethics that are sensitive to the world of ICT, specifically in MALL, are related to ethical considerations. Those concerned about ethical issues believe that utilizing MALL is akin to wielding a two-edged sword. MALL has the potential to improve language teaching and learning outcomes, but it also has some undesirable ethical consequences. One example is that students may reveal private or personal information to the general public. Furthermore, kids with more advanced mobile devices may abuse others with outdated versions. Indeed, as a result of the widespread use of smartphones, the number of incidences of cyberbullying has skyrocketed (Campbell, 2005). According to Charlton, Panting, \& Hannan (2002), those who do not own phones in the UK are at risk of social exclusion. The students' unrestricted access to the internet may drive them to view pornographic material. Scams and fraud are examples of ethical dilemmas that might arise in the social media world (Ali, 2018).

\section{Challenges related to the mobile devices and applications}

The mobile devices and applications themselves may provide a challenge to MALL's success in foreign language teaching and learning. One of the challenges is the size of the phone's screen. Phones with varying screen sizes may be used by different students. According to Chinnery(2006), successful adoption of MALL such as PDAs has hurdles due 
to their portability, which results in reduced screen sizes. Another issue is audiovisual quality, which may be restricted to some students. Students with hearing impairments may have difficulty using the gadget in this situation. Another limitation is the smaller keyboard for data entry. Because the screen does not always match their fingertips, it might be difficult for students and teachers to type a set number of words in a given amount of time in the classroom. Mobile phones also require SD cards for additional data storage, and all mobile devices have a limited battery life (Wishart, 2008).

\section{Challenges pertaining to the conditions of some regions in Indonesia}

The majority of mobile gadgets are pricey to purchase. In some cases, students in Indonesia may not be able to afford a smartphone. Furthermore, certain programs require constant internet access and regular updates. This can be a concern in many of Indonesia's undeveloped areas $(\mathrm{Oz}, 2015)$. Many areas do not yet have access to the internet or even electricity. The cost of obtaining a strong internet connection in schools should likewise be "excellent." Otherwise, teachers and students would have to rely on the offline aspects of their mobile devices and programs to learn English.

\section{The possibilities of MALL to be used in Indonesian context}

Integrating MALL into the teaching and learning of English as a foreign language in an Indonesian context presents a plethora of opportunities for both teachers and students to engage in cutting-edge teaching and learning approaches. Indonesia is a developing nation with English as a second language (Cahyono \& Widiati, 2004). Internet connection has been available in major cities and towns, while it is still limited in other areas (Jazadi, 2008). Nonetheless, Indonesia has over 13.000 islands, each with its own distinct qualities and personality. There is no electricity in many rural places, let alone internet connectivity. Furthermore, the above-mentioned problems of implementing mobile technology gadgets and applications appear to apply to practically all stakeholders (to teachers, students, and communities). Many teachers still lack the confidence and skill to use technology, schools, and students continue to be unable to buy mobile devices, and some members of the public suffer from technophobia. These obstacles may deter instructors, students, and the government from using MALL in the classroom to teach English as a foreign language (Salehi \& Salehi, 2012).

Furthermore, studies on the inclusion of MALL into English language teaching and learning in the Indonesian setting are still restricted, despite the fact that many have tried to employ it in their teaching activities. Some studies have been conducted to look at the perspectives of students and teachers on the use of mobile phones in general (Yudhiantara \& Nasir, 2017; R. A. Yudhiantara \& Saehu, 2017). However, detailed examinations into the use of specific mobile devices and applications in teaching English as a foreign language in various parts of Indonesia, particularly rural areas, have been few and far between. Yudhiantara \& Saehu (2017), for example, explored how tertiary education students in Indonesia utilize their mobile phones to support their English language learning in general, 
as well as how they used it to learn English Monolingual Dictionary (MED) application. The study by Chairunnisa and Benedictus (2017) focused on the emoticons used in Whatsapp and Blackbarry in Indonesia's capital. These investigations are quite promising and should be expanded to other locations in Indonesia.

However, because technology is always evolving in this digital age, teachers essentially have no choice but to stay up with every breakthrough in information technology in order to keep their teaching current, particularly in MALL. All of the capabilities of the mobile devices and applications stated above can lead to a variety of language learning activities such as communicative language practice, task fulfillment, and access to authentic language content in language learning. Other tasks such as studying vocabulary and terms or idioms, locating or searching for definitions of words, and looking for example sentences can also be used (Chinnery, 2006).

Additionally, both teachers and students can use free tools and programs for English teaching and learning via mobile devices and apps. They can download the EnglishIndonesia dictionary, Easy English Dictionary offline Voice Word Meaning, and Word Games to their PDAs. There are also free programs available through their Facebook profiles, such as BBC News, English Speaking Partners, and American Accent. Whatsapp also offers a variety of educational opportunities with its emoticons, audio, text, and video call functions.

After considering the advantages and disadvantages of using the aforementioned mobile devices and applications, it appears that using MALL in the Indonesian setting can provide numerous benefits. PDAs and Tablets can still be utilized for teaching and learning activities in regions where internet access is not available (Chinnery, 2006; Godwin-Jones, 2011). Offline, they can still be used. Furthermore, in order to foresee the challenges that would come with their implementation in teaching and learning English, the collaboration between the government, teachers, students, and other EFL stakeholders should be prioritized. The government can assist by developing legislation and giving funding for MALL implementation. The provision of power should be a top priority. Teachers and students may help by always attempting to comprehend and improve their abilities to use apps and mobile devices. Other stakeholders can help by offering support in the home and in the community.

\section{CONCLUSION}

Finally, mobile devices and apps have been included in the teaching of English as a foreign language. This occurs in a variety of places around the world, including Indonesia. While there are limitations to implementing MALL in the Indonesian environment, the prospects to improve English language learning results and keep up with the latest educational innovations are encouraging. As a result, MALL should be implemented in Indonesia as a developing country while keeping in mind the obstacles that it may provide to all stakeholders. To deal with those issues, wise actions and remedies should be 
performed. There has not been much research on the usage of certain mobile devices and apps for teaching English as a foreign language in Indonesia, particularly in rural areas. As a result, more research is needed to determine whether certain mobile devices and applications may be utilized throughout Indonesia.

\section{REFERENCES}

Ahmad, K. S., Armarego, J., \& Sudweeks, F. (2013). Literature review on the feasibility of mobile-assisted language learning (MALL) in developing vocabulary skills among nonEnglish speaking migrant and refugee women. Paper presented at the Research and Innovation in Information Systems (ICRIIS), International Conference.

Ali, M. (2018). 10+ the advantages and disadvantages of social media on youth. Retrieved February 24, 2008, from https://adilblog.com/advantages-disadvantages-socialmedia-youth/

Awada, G. (2016). Effect of WhatsApp on critique writing proficiency and perceptions toward learning. Cogent Education, 3(1), 126-173.

Bensalem, E. (2018). The impact of WhatsApp on EFL students' vocabulary learning. Arab World English Journal (AWEJ), 9(1), 23-38. doi:https://dx.doi.org/10.24093/awej/vol9no1.2

Boyd, D., \& Ellison, N. (2007). Social network sites: Definition, history, and scholarship. Journal of Computer \& Mediated Communication, 13(1), 210-230.

Cahyono, B. Y., \& Widiati, U. (2004). The tapestry of English language teaching and learning in Indonesia. Malang: State University of Malang Press.

Campbell, M. (2005). The Impact of the Mobile Phone onYoung People's Social Life. Paper presented at the the Social Change in the 21st Century Conference.

Chairunnisa, S., \& Benedictus, A. (2017). Analysis of emoji and emoticon usage in interpersonal communication of Blackberry messenger and WhatsApp application user. International Journal of Social Sciences and Management, 4(2), 120-126.

Charlton, T., Panting, C., \& Hannan, A. (2002). Mobile telephone ownership and usage among 10- and 11-year-olds: Participation and exclusion. Emotional \& Behavioural Difficulties, 7(3), 152-163.

Chinnery, G. M. (2006). Emerging technologies going to the MALL: Mobile assisted language learning. Language Learning \& Technology, 10(1), 9-16.

Chuang, K. W. (2009). Mobile technologies enhance the e-learning opportunity. American Journal of Business Education, 2.

Ebner, M., Lienhardt, C., Rohs, M., \& Meyer, I. (2010). Microblogs in higher education-a chance to facilitate informal and process-oriented learning? . Computers \& Education, 55(1), 92-100.

Espinosa, L. F. (2015). The use of facebook for educational purposes in EFL classrooms. Theory and Practice in Language Studies, 5(11), 2206-2211. doi:http://dx.doi.org/10.17507/tpls.0511.03 
Franks, T. M. (2016). Purpose, practice, and (discovery) process: When self-reflection is the method. Qualitative Inquiry, 22(1), 47-50.

Godwin-Jones, R. (2011). Emerging technologies: Mobile apps for language learning. Language Learning \& Technology, 15(2), 2-11.

Hamad, M. M. (2017). Using WhatsApp to enhance students' learning of English language "experience to share". Higher Education Studies, 7(4), 74.

Hsu, L. (2016). Examining EFL teachers' technological pedagogical content knowledge and the adoption of mobile-assisted language learning: A partial least square approach. Computer Assisted Language Learning, 29(8), 1287-1297.

Jang, M., \& Song, W. O. (2007). Personal digital assistants: Essential tools for preparing dietetics professionals to use new generation information technology. Nutrition Research and Practice, 1(1), 42-45.

Jazadi, I. (2008). The Politics of Curriculum; An Interpretive Stduy of High Schools in Indonesia. Sumbawa: Paracendekia NW Press.

Lan, Y.-J., Y. -T. Sung, \& Chang, K.-E. (2007). A mobile-device-supported peer-assisted learning system for collaborative early EFL reading. Language Learning \& Technology, 11(3), 130-151.

Lombok Post. (2020). Tiga Ribu Desa di Indonesia tanpa Listrik, 11.000 tanpa Internet. Retrieved January 20, 2021, from https://lombokpost.jawapos.com/nasional/11/08/2020/tiga-ribu-desa-diindonesia-tanpa-listrik-11-ribu-tak-ada-internet/

Menkhoff, T., Chay, Y. W., Bengtsson, M. L., Woodard, C. J., \& Gan, B. (2015). Incorporating microblogging ("tweeting") in higher education: Lessons learnt in a knowledge management course. Computers in Human Behavior, 51, 1295-1302.

Merdeka.com. (2020). 5.000 Keluarga di Sumbawa Belum Menikmati li. Retrieved January 20, 2021, from https://www.merdeka.com/peristiwa/5000-keluarga-di-sumbawabelum-menikmati-listrik.html

Mwakapina, J. W., Mhandeni, A. S., \& Nyinondi, O. S. (2016). Whatsapp mobile tool in second language learning: Opportunities, potentials and challenges in higher education settings in Tanzania. International Journal of English Language Education, 4(2), 7090.

Nations, D. (2018). What is Microblogging? A Definition of Microblogging with Examples. Retrieved October 9, 2018, from https://www.lifewire.com/what-is-microblogging$\underline{3486200}$

Noordin, N., \& Ting, D. S. W. (2017). Facebooking in today's net generation: Prospects and challenges. The English Teacher(1), 14.

Oxford University Press ELT, O. U. P. (2016). 25 Ideas for Using WhatsApp with English Language Students. Retrieved from https://oupeltglobalblog.com/2016/05/17/25ideas-for-using-whatsapp-with-english-language-students/ 
Oz, H. (2015). An investigation of preservice English teachers' perceptions of Mobile Assisted Language Learning. English Language Teaching, 8(2), 22-34.

Ozdogan, M., Basoglu, N., \& Ercetin., G. (2012). Exploring major determinants of mobile learning adoption. Proc. Technology Management for Emerging Technologies (PICMET), 1415-1423.

Park, S., Kim, M., Lee, Y., Son, C., \& Lee, M. (2005). The effects of visual illustrations on learners' achievement and interest in PDA-(Personal Digital Assistant) based learning. Journal of Educational Computing Research, 33(2), 173-187.

Princeton University Library. (2021). Philosophy: Library research methods. Retrieved February 3, 2021, from https://libguides.princeton.edu/c.php?g=84018\&p=664971

Salehi, H., \& Salehi, Z. (2012). Challenges for using ICT in education: Teachers' insights. International Journal of e-Education, e-Business, e-Management and e-Learning, 2(1), 40-43.

Savas, P. (2014). Tablet PCs as instructional tools in English as a foreign language education. Turkish Online Journal of Educational Technology-TOJET, 13(1), 217-222.

Sugiyono. (2010). Metode Penelitian Kuantitati,f Kualitative dan $R \& D$. Bandung: Alfabeta.

The Statistic Portal. (2018). Most Popular Mobile Messaging Apps Worldwide as of July 2018, based on umber of monthly active users (in millions). Retrieved October 8, 2018, from https://www.statista.com/statistics/258749/most-popular-global-mobilemessenger-apps/

Wishart, J. (2008). Challenges faced by modern foreign language teacher trainees in using handheld pocket PCs (Personal Digital Assistants) to support their teaching and learning. ReCALL, 20(3), 348-360.

Yang, J. (2013). Mobile assisted language learning: review of the recent applications of emerging mobile technologies. English Language Teaching, 6(7), 19.

Yudhiantara, R., \& Nasir, I. A. (2017). Toward mobile-assisted language learning (MALL): Reaping mobile phone benefits in classrooma activities. Register Journal, 10(1), 1228.

Yudhiantara, R. A., \& Saehu, A. (2017). Mobile-assisted language learning (MALL) in Indonesian Islamic Higher Education. IJELTAL (Indonesian Journal of English Language Teaching and Applied Linguistics), 2(1). 